\title{
The Eurodollar Market: The Case for Disclosure
}

\author{
Ronald David Greenberg†
}

The Eurodollar market has been with us in significant dimensions for approximately two decades, ${ }^{1}$ but its ramifications continue to be explored. ${ }^{2}$ Economists and other authorities disagree about the nature and rate of deposit expansion in the Eurodollar market, ${ }^{3}$ whether and to what extent the Eurodollar market feeds worldwide inflationary forces, ${ }^{4}$ and whether Eurodollar lenders take greater risks when making their loans than do other lenders. ${ }^{5}$ These economic consequences

$\dagger$ Adjunct Professor, Columbia University School of Busimess; B.S. 1957, University of Texas; M.B.A. 1961, J.D. 1964, Harvard University. The author is Chairman of the Committee of Taxation, American Bar Association, General Practice Section, and Chairman of the Committee on Tax Law, New York State Bar Association, General Practice Section. The views expressed in this Article are his own and do not necessarily reflect the views of either the American Bar Association or the New York State Bar Associatiou. The author gratefully acknowledges the assistance of Max Holmes, Columbia Law School 1984. The author also gratefully acknowledges the earlier assistance of John Arnold, Stanford Law School 1979; Tom Manning, Stanford Busmess School 1979; and Robert Mattson, Columbia Busmess School 1981.

1. For a brief history of the Eurodollar, see Holmes \& Klopstock, The Market for Dollar Deposits in Europe, 42 FED. RESERve BANK N.Y. MONTHLY REV. 197 (1960); Klopstock, The International Money Market: Siructure, Scope and Instruments, 20 J. Fin. 182, 203.08 (1965). For example, in 1976, the size of the market was estimated at $\$ 285$ billion. Kilborn, Eurodollar Market Booming in London, N.Y. Times, Dec. 25, 1976, at 19, col. 3. In 1980 it was estimated at $\$ 1,150$ billion. Janssen, Experts at Wharton Euromart Seminar Concede Their Subject Baffes Them, Wall St. J., July 18,1980 , at 16 , col. 1.

2. See, e.g., G. Beli, The Euro-dollar Market and the International Financial System 14-17 (1973); P. Einzig \& B. Quinn, The Eurodollar System: Practice \& Theory OF INTERNATIONAL INTEREST RATES (6th ed. 1977); Calhoun, Eurodollar Loan Agreements: An Introduction and Discussion of Some Special Problems, 60 J. Com. Bank Lending 23 (1977); Machlup, Five errors about the Eurodollar system, EuROMONEY, July 1972, at 8, 14. For an overview of international banking, see S. Davis, The EuRo-Bank: Its Origins, MANAGEMENT AND OutLooK (2d ed. 1980); M. MAyer, THe Bankers 431-83 (1974); S. Robinson, Multinational BANKING (1972); Dean \& Grubel, Regulatory Issues and the Theory of Multinational Banking, in Issues in Financial Regulation 405 (F. Edwards ed. 1979).

3. See infra note 16 and accompanying text.

4. See, eg. J. LitTle, Euro-Dollars: The Money-Market Gypsies 141-42, 150 (1975).

5. Lenders in the Eurodollar market take greater risks, according to E. CLENDENNING, THE Euro-Dollar MARKet 163-64 (1970); P. Einzio \& B. QUINN, supra note 2, at 57-61; S. Davis, supra note 2, at 137; Bell, The Eurocurrency market: the next steps, EUROMONEY, July 1972, at 16; Holmes \& Klopstock, supra note 1, at 201; F. Klopstock, Structural Changes in Euro-Currency Banking 4 (Fed. Reserve Bank N.Y. May 10, 1972) (unpublished manuscript on file with the California Law Review). For the opposing view, see J. LiTTLE, supra note 4, at 132; Lee, The Eurodollar Market Revisited, 156 BANKERS MAG. 64, 64-69 (1973). 
and risks, in turn, generate questions of regulation. Should the inarket be regulated? Can it be? How? And by whoin?

The purpose of this Article is to suggest that the Eurodollar market be regulated to some extent, and that the inethod of regulation best suited for the current market is solne form of disclosure by the banks about their Eurodollar loans. ${ }^{6}$ This information, subject to review by a supranational agency, would assist the Euro-banks ${ }^{7}$ in evaluating the risks of contemplated loans.

Part I presents a brief description of the Eurodollar inarket, including Eurodollar deposit expansion, and its attendant inflationary risks. Part II discusses the oft-criticized lending practices of Eurobanks. Part III argues that although regulations of Euro-bank operations may be desirable, the international character of the Eurodollar market makes coinprehensive regulatory strategies unfeasible. Finally, Part IV proposes the creation of a systein of disclosure to assist Eurobanks in the proper evaluation of risk, without unnecessarily hainpering their Eurodollar operations.

\section{I}

\section{The Eurodollar MARKeT}

Eurodollars are time deposits of dollars in foreign commercial banks or foreign branches of American banks. ${ }^{8}$ These deposits typically arise in two ways. First, they may result from American purchases (in dollars) of goods or services from European suppliers (or non-European suppliers who maintain European bank accounts, e.g., countries belonging to the Organization of Petroleum Exporting Coun-

6. Thirty-five international banks have recently formed a clearinghouse to collect financial information on foreign countries having probleins repaying their debts. Hershey, Worldwide Debt Data for Banks, N.Y. Times, Jan. 12, 1983, at D2, col. 3. This action is an important first step since probleın loans of countries are significant eleınents in international banking. However, information on significant loans to other borrowers, both governments and corporations, shonld also be gathered.

7. Banks that participate in Eurodollar transactions will be referred to as Euro-banks.

8. See, e.g., Holmes \& Klopstock, supra note 1, at 197. The term Eurodollar, or its broader counterpart Eurocurrency, is something of a misnomer, since a good portion of the inarket's activity has come to be conducted outside Europe. S. ROBINSON, supra note 2, at 163. For example, dollars held in the Far East have sometimes been called Asiadollars. See, e.g., Hollie, Singapore: Banker to Region, N.Y. Times, Jan. 23, 1981, at D1, col. 2; Witcher, Singapore's Booming Asiadollar Market Is Attracting Some More American Firms, Wall St. J., Mar. 26, 1980, at 18, col. 1. Eurobonds, including Zero-Coupon Eurobonds, also exist. See, e.g., Rattner, Zero-Coupon Eurobonds a Hit, N.Y. Times, Feb. 3, 1982, at D1, col. 3; Foldessy, Novel Way is Found For the Sale of Bonds In Eurodollar Sector, Wall St. J., Oct. 14, 1980, at 42, col. 1. There is even a futures market in Eurodollars. See, e.g., Maidenberg, Eurodollar Acceptance Spreading, N.Y. Times, Feb. 1, 1982, at D5, col. 4; Maidenberg, New Eurodollar Market, N.Y. Times, Dec. 14, 1981, at D6, col. 2; Eurodollar Futures Trading Is Started at Mercantile Exchange, Wall St. J., Dec. 10. 1981, at 42, col. 1. 
tries). Second, these deposits may be derived from investments of Americans who, attracted by the higher interest rates prevailing abroad, place dollars in foreign bank accounts. Foreign banks accept these deposits to relend them at even higher rates.

Although foreign currency accounts have existed in banks since the beginning stages of banking, the Eurodollar market came into prominence in the late 1950's, particularly after most European countries removed their exchange restrictions. ${ }^{9}$ The first clients of Eurodollar marketers were Eastern European interests who wanted to keep their dollar balances in French and Englisli correspondent banks instead of in the United States. ${ }^{10}$ This market matured in the 1960's, as a result of large expenditures that the United States made abroad for foreign aid, defense, investment, and imports, and as a result of various national-principally American-banking regulations which encouraged the development of an unregulated international money market. ${ }^{11}$

Most European countries treat the Eurodollar accounts of their banks very differently from domestic currency accounts. Eurodollar accounts are not subject to minimum reserve requirements and other domestic banking regulations. ${ }^{12}$ This disparate treatment creates both advantages and disadvantages. To the extent that either burdensome or obsolescent regulatory strictures are avoided, foreign banks can allocate Eurodollar resources more efficiently. The absence of a lender of last resort ${ }^{13}$ and the elimimation of regulatory controls, such as currency reserves, however, expose the Eurodollar systein to deposit expansion and to the inflationary pressures that accompany it.

Deposit expansion occurs when a Euro-bank relends those Eurodollars funds that have been deposited with it. Each new deposit transfers, in whole or in part, ownership of the origmal deposit held in a bank in the United States. Each redeposit creates new Eurodollar deposit liabilities on the balance sheet of the Euro-bank involved, and the total Eurodollars created may be several times the amount of the original claim on the Euro-bank. ${ }^{14}$ The quantitative measure of this

9. S. RoBinson, supra note 2, at 156. The elimination of exchange restrictions under the terms of the 1955 European Monetary Agreement meant that a nonresident, regardless of nationality, could convert currency that he legally held into any other currency. Thus, a inajor obstacle to the free movement of capital was eliminated.

10. This was motivated largely because of the fear on the part of these depositors that dollar accounts in United States banks might be blocked in times of political uncertainty or crisis. S. RoBinson, supra note 2, at 164.

11. S. DAvis, supra note 2, at 27; P. Einzig \& B. Quin,, supra note 2, at 24.

12. See infra note 24 and accompanying text.

13. S. Robinson, supra note 2, at 258.

14. Snellings, The Euro-Dollar Market, in INSTRUMENTS OF THE MONEY MARKET 87, 90 (J. Monhollon 2d ed. 1970). 
expansion of deposits in the Eurodollar market is the Eurodollar multiplier. The multiplier is simply the total dollar accounts resulting from the introduction of each dollar into the Eurodollar inarket. ${ }^{15}$

The inflationary pressure resulting from foreign ownership of dollars depends in part on the degree of this deposit expansion in the Eurodollar market. ${ }^{16}$ Inflation results when the expansion process increases the supply of money, ${ }^{17}$ without a corresponding increase in the production of goods and services. ${ }^{18}$

In the Umited States, a portion of every dollar deposited with a bank is removed from circulation because of federally imposed reserve requirements. ${ }^{19}$ These requirements are imposed to ensure that a bank will be able to meet its depositors' demands to withdraw funds. Reserve requireinents limit the net effect of an increase in the money supply by the Federal Reserve System, thus reducing the inflationary effect of such an action. ${ }^{20}$

In the Eurodollar inarket, Euro-banks are usually not subject to any reserve requirements. Therefore, unlimited deposit expansion is theoretically possible. Three marketplace events tend either to inhibit or to stop Eurodollar deposit expansion. First, the foreign banks may

15. The literature on Eurodollars is replete with various models that purport to explain Eurodollar deposit creation or expansion. See, e.g., Stem, Some Eurocurrency Problems: Credit Expansion, the Regulatory Framework, Liquidity, and Petrodollars, in EUROCURRENCIES AND THE InTERnATIONAL MONETARY System 295-303 (C. Stem, J. Makin \& D. Logue eds. 1976) [hereinafter cited as EUROCURRRENCIES]. The literature also describes this phenomenon in the context of credit creation and expansion.

16. See Efiros, The Whys and Wherefores of Eurodollars, 23 Bus. LAw. 629, 633-34 (1968); Friedman, The Euro-Dollar Market: Some First Principles, 53 FED. RESERve BANk St. Louis Monrhly Rev. 16 (1971); Klopstock, Money Creation in the Euro-Dollar Market-A Note on Professor Friedman's Views, 52 FED. RESERve BANK N.Y. MONTHLY REV. 12 (1970).

It has been argued that Eurodollar deposits flowing from the United States to foreign countries are inflationary in themselves, even without a large multiplier effect. Machlup, The Eurodollar System and Its Control, in International Monetary Problems 3, 11-14 (Am. Enterprise Inst. for Pub. Poly Research 1972) (with respect to the quantity of certain sources of new dollars deposited in the Eurodollar market); id. at 17-18 (with respect to the velocity or efficiency with which existing stocks of money are used).

17. It could be argued that the expansionary effects of the Eurodollar market are not particularly helpful in understanding the growth of the money supply or inflation, since Eurodollars, as time deposits, are short-term imvestments rather than money. See J. LITTLE, supra note 4, at 15659. But see Machlup, supra note 16, at 17 (disputing this contention).

18. Even if it is assumed that Eurodollars are money, the relationship between the money supply and mfiation is not entirely clear. See EuRocurRENCIES, supra note 15, at 292-93.

19. See P. SAMUElson, Economics 286-88 (1 lth ed. 1980).

20. In the United States, for example, if it takes three to four days for checks to be cleared and decisions to be made at each stage of the lending process, then perhaps five to eight weeks would be required for the process to substantially work its way through more than a dozen rounds. At the end of twelve rounds, an original deposit of $\$ 1$ million, for instance, could theoretically create $\$ 3.66$ million in new deposits, assuning a $20 \%$ reserve requirement. The process would thus be $93.2 \%$ complete, since the $\$ 4.66$ million would be outstanding against an upper limit of $\$ 5$ million. See P. SAMUELSON, supra note 19, at 287. 
simply choose not to relend their available dollar deposits. ${ }^{21}$ Second, foreign banks may transfer the deposits back to the United States, for example by lending to importers of Umited States goods, by purchasing securities from a United States resident, or by placing the dollars in a time deposit account in the United States. ${ }^{22}$ As ownership of dollar deposits abroad is transferred to residents of the United States, the Eurodollar deposits cease to expand. ${ }^{23}$ Third, the dollar deposits may not give rise to lendable funds because of regulatory prohibitions. ${ }^{24}$

The possibility of any one of these events occurring, however, is too uncertain a prospect on which to rely for monetary regulation. It must be considered, therefore, that the process of deposit expansion in Eurodollar markets remains virtually unchecked. It is necessary, therefore, to examine the lending practices of the Eurodollar inarket to see whether this recycling of deposits is based on a strong foundation of prudent banking practices.

II

\section{Lending Practices in the Eurodollar Market}

Lending practices in the Eurodollar market have been the subject

21. Id. at $290-91$.

22. In tracing "leakages," Little concludes:

[T] he purchaser-be he a private citizen or a central bank intervening to keep the price of his currency from rising too high-may spend the dollars inside the United States (a leak) or outside the United States (again indeterminate), or he may place them in the Euro-dollar market (eureka, a feedback). In other words, of the three alternatives facing all Euro-dollar loan recipients (spending the dollars in the United States, passing them on to other foreigners either directly or through the foreign-exchange inarket and depositing them in the Euro-dollar inarket), only one course represents a feedback.

J. LITTLE, supra note 4, at I51. It should be mentioned that the indetermmate alternative cited by Little may or may not result in a feedback, and thus Little's conclusion that "only one course represents a feedback" might more fairly be stated as between one-third and two-thirds of the courses represent feedbacks. But see Machlup, supra note 16, at 25, for a discussion of the possibihty that leakage is very small because feedbacks from Eurodollar lending can asymptotically approach $100 \%$ within a brief period under certain conditions. Regarding domestic money supply leakage into hand-to-hand circulation, see P. SAMUELSON, supra note 19, at 290.

23. J. LiTTLE, supra note 4, at 151-56, 159.

24. StafF of Subcomm. on International Exchange and Payments of the Joint Economic Comm., 87th Cong., 2D Sess., Factors Affecting the United States Balance OF PAYMENTS 539 (Comm. Print 1962); J. LitTLE, supra note 4, at 147-51. In October 1979, the United States Federal Reserve Board established an eight percent reserve rcquirement on purchased funds raised by banks. See Arenson, Fed Acts as High Rates Prove Inadequate, N.Y. Times, Oct. 9, 1979, at D5, col. 3. The reserve requirement was increased to ten percent im March 1980. See Farnsworth, Fed Puts Surcharge on Discount Rate: 3-Point Rise to Cut Lending, N.Y. Times, Mar. 15, 1980, at 25, col. 5. Under the Bank Act of 1954, 48 CAN. REv. STAT. $\$ 71$, Canadian banks are required to maintain "adequate reserves" against habilities in foreign currencies. Whether these "reserves" can be held in foreign currencies is not explicitly statcd, and "adequate" is nowhere defined. See also Holmes \& Klopstock, supra note I, at 201 (Until July I, 1960, German banks were encouraged to accept Eurodollar bank liabilities, if offset by a foreign currency asset.). 
of considerable scrutiny ${ }^{25}$ and a source of uneasiness to many observers. $^{26}$ A brief survey of Eurodollar lending activities provides an essential backdrop to this Article's investigation of whether the market should be regulated. While reviewing these practices, it should be reinembered that although soine of the problems connected with Eurodollar loans are shared by every commercial bank, ${ }^{27}$ the international dimension and other factors peculiar to Eurodollar banking make the scope of the credit risk broader and its implications more profound. ${ }^{28}$

\section{A. The Risks}

\section{Lack of Information}

Lack of information is one of the most troubling aspects of Eurodollar banking. Prudent banking practice might suggest that short-term credit be provided only in the form of self-hquidating loans, i.e., to those businesses that can fund imterest and primcipal payments directly from the operation that receives the loan. Eurodollar loans are rarely lent in this manner. In fact, many Eurodollar loans are made without the lending bank even knowing the identity of the final borrower. 29

One important factor contributing to this lack of lender informa-

25. See, e.g., G. BELl, supra note 2, at 33-39; S. RoBINSON, supra note 2, at 252-58; Shootout Between Congress, Banks Develops Over Bad Foreign Loans, Wall St. J., Feb. 2, 1983, at 29, col. 4 (quoting a New York bank consultant as stating " The very big banks . . . let the money pour out without evaluating the risks.' "); The Central Bankers Call for Discipline, Bus. WK., Sept. 6, 1982, at 83 (central bankers contend banks ignored risks on some foreign loans on assuinption that some official body would bail them out); Lewis, Eurodollar Curb Plan Reported, N.Y. Times, Nov. 12, 1979, at DI, col. 6 (reporting position of Federal Reserve that "Eurocurrency inarkets represent a serious leak in [countries'] monetary controls and are thus a source of world inflation as well as a temptation to imprudent bankers to lend more than is wise"); F. Klopstock, supra note 5, at 5-10; The Euro-dollar Market, Fed. Reserve BAnk Clev. Econ. PAPers, June 1970, at 28; Weinert, Eurodollar Lending to Developing Countries, ColuM. J. WoRLD Bus., Wimter 1973, at 34.

26. See supra note 25; infra notes 37 \& 44. See also Lever, International Banking's House of Cards, N.Y. Times, Sept. 24, 1982, at A27, col. 2 (noting unregulated Eurodollar lending, bank cash flow probleins, de facto borrower defaults, many shaky government and private corporate borrowers and recommending the establishment of a government committee "to decide in broad terms the overall annount of future lending necessary in the general economic and political imterest," with the International Monetary Fund (IMF) as "one of the main agencies in discharging these obligations.")

27. See E. Clendenning, supra note 5, at 163.

28. Id.; Dufey \& Giddy, The Unique Risks of Eurodollars, 60 J. CoM. BANK LENDING 50, 5358 (1978).

29. Id. at 58. See also Worry at the World's Banks, Bus. WK., Sept. 6, 1980, at 16, col. 1; S. RoBInson, supra note 2, at 252; Former Morgan Officer in Waterhouse Venture, N.Y. Times, May 6, 1983, at D2, col. 4 (quoting former head of Morgan Guaranty Trust Coinpany's international banking division as stating " '[P]eople don't know how inuch they borrowed. Problems arise too quickly. Too much is borrowed on wrong terms and they get beyond themselves without even knowing it in soine cases." "); Bennett, Bankers Said to Plan Meeting on World Debt, N.Y. Times, 
tion is the practice of international risk spreading. To diversify their lending portfolios, most Euro-banks spread their loans among several countries and several borrowing banks. ${ }^{30}$ The borrowers are then free to relend these dollars without disclosing the identities of their recipients to the original lender. The Euro-bank may not know, for example, whether its borrower plans to use the funds to finance foreign trade, to finance domestic trade, to engage in speculation, or to relend. ${ }^{31}$ If these funds are re-lent, the original banks apparently do not know who the borrowers are or to what use the funds will be put. ${ }^{32}$

Given the scanty credit information and the general anonymity of borrowers in the Eurodollar narket, Euro-banks are not able to judge the scope of the credit risks involved ${ }^{33}$-at least not to the same degree as in domestic banking operations. ${ }^{34}$ One result of such poor imterbank communication is that several banks may unknowingly overlend to a single borrower, who inay be unable to meet its obligations. ${ }^{35}$ Without a clear legal structure under which the resolution of a default by a major borrower (such as a sovereign government with a large loan) might be pursued, a failure might generate a domino effect of failures. ${ }^{36}$ The problems for banks when a typically sized corporate debtor defaults pale in comparison to what might liappen to the world's financial markets if a major Eurodollar borrower defaulted. ${ }^{37}$

Oct. 20, 1982, at D1, col. 1 ("Often the countries themselves have had no satisfactory information about the loans they have borrowed or when their debts would mature.").

30. See Holmes \& Klopstock, supra note 1, at 199.

31. Weinert, supra note 25 , at 65 . Nor does the original lender know whether the loan is for commercial purposes or is self-hquidating. P. EINZIG \& B. QUINN, supra note 2, at 58.

32. Gerth, Worries on Lending Abroad, N.Y. Times, Nov. 12, 1982, at D1, col. 2; P. EinziG \& B. QuINN, supra note 2, at 58.

33. Effros, supra note 16 , at 644 .

34. E. Clendenning, supra note 5, at 163.

35. Id. One example of this is a concentration of Eurodollar loans to oil exporting countries. See Morgan Guaranty Trust Co., Eurocurrency Market Developments, WORLD FIN. MARKETS 4, 8 (July 1974).

36. See, e.g., Bergsten, World Financial Crisis, N.Y. Times, Aug. 26, 1982, at A27, col. 1 ("The key issue is whether there is a prospect of simultaneous difficulties in a number of debtor nations and whether such an eventuality could threaten the stability of the world monctary system.").

37. See, e.g., Taghabue, A Surge of Fallures in Europe: Insolvencies Are Highest Since War, N.Y. Times, Sept. 15, 1982, at D1, col. 2; Pine, Lenders' Jitters: International Bankers Take Steps to Restore Faith in Their System, Wall St. J., Sept. 15, 1982, at 1, col. 6 (listing the biggest debtor nations by "Total Debt" and "Loans from Private Banks"); Silk, Avalanche of Debt Threatens Global Economy, N.Y. Times, Sept. 12, 1982, \&4 (Week in Review), at 3, col. 1 (quoting D. Healey, former British Chancellor of the Exchequer: "The risk of a major default [of a dcbtor country such as Mexico, Poland, and Argentina] triggering a chain reaction is growing every day."); Garten, A World Banking Peril, N.Y. Times, Sept. 9, 1982, at A27, col. 1; Silk, Threatened Money System, N.Y. Times, Sept. 8, 1982, at D2, col. 1; Silk, Faith and the Banks: Those at the 1.M.F. Meetings Are Cautious About Ability to Save Others from Collapse, N.Y. Times, Scpt. 7, 1982, at A1, col. 5; Silk, Capitalism and Crises, N.Y. Times, Sept. 1, 1982, at D2, col. 1 ("The world economic systein is suffering the inost acute stress it has known in half a century."); World's Financial 


\section{Lack of Security}

A second disturbing aspect of Eurodollar loan agreements is that they give the lenders little security against default. Euro-bank loans are usually unsecured. ${ }^{38}$ Unless voluntarily adopted by the borrower, few of the covenants found in the elaborate loan agreeinents used in the United States exist in Eurodollar agreements. ${ }^{39}$ The Eurodollar loans seldom provide for amortization of principal over the life of the loan, nor is the repayment schedule matched with the borrower's cash flow. ${ }^{40}$ Covenants specifying minimum levels of working capital to be maintained by the borrower, minimum ratios of current assets to current habilities, and minimum ratios of total assets to total liabilities, are rarely included. ${ }^{41}$ Without these protections, the risk of default increases greatly.

\section{Weakness of Eurodollar Borrowers}

Another factor that increases the risks associated with Eurodollar loans is the general financial instability of certain Eurodollar borrowers. Euro-banks make a substantial portion of their loans to developing countries and private firms located in developing countries. ${ }^{42}$ Some of these borrowers could not obtain credit in standard banking channels because of the close financial scrutiny required by donestic regulations. ${ }^{43}$

Scandals, Debt Crises Rocking International Banking System, Wall St. J., Aug. 25, 1982, at 22, col. 1 (Some bankers believe that there is a "serious crisis building."); see also infra note 44 and accompanying text.

38. See The Euro-dollar Market, supra note 25, at 28; Weinert, supra note 25, at 65 .

39. F. Klopstock, supra note 5, at 6; Newburg, Financing in the Euromarket by U.S. Companies: A Survey of the Legal and Regulatory Framework, 33 Bus. LAw. 2171 (1978).

Lack of contractual boilerplate could be explained by the fact that the financial standing of Eurodollar borrowers is so high that extensive protective covenants are not considered necessary. See P. Einzig \& B. QuinN, supra note 2, at 58.

40. F. Klopstock, supra note 5, at 6 .

41. Id.

42. See, e.g., Morgan Guaranty Trust Co., supra note 35, at 6; Weinert, supra note 25, at 35. See generally A Reporter's Notebook: Bankers in a Leaky Boat, N.Y. Times, May 28, 1982, at D1, col. 1; Bennett, Banking on the U.S. for Stability, N.Y. Times, Feb. 14, 1982, \& 12 (International Economic Survey), at 27, col. 1; IMF, World Bank Delegates Tacilly Back Push by U.S. to Tighten Lending Policies, Wall St. J., Oct. 1, 1981, at 13, col. 1; Banks Trim Loans to Third World Amid Fears of Repayment Problem, N.Y. Times, Apr. 14, 1980, at A1, col. 4; Miller, Sounding Alarms on Foreign Debt, N.Y. Times, Sept. 18, 1977, $\$ 3$ (Business and Finance), at 1, col. 1.

43. Even American banks and their customers have at times nsed the Eurodollar market to avoid banking restrictions placed on thein at hoine. For instances where this has liappened in the past, see Dodging the Fed: Fearing Curbs on Borrowing, Many Firms Negotiate Credit Lines at Foreign Banks, Wall St. J., Apr. 17, 1980, at 44, col. 1; Billions in Eurodollars Were Borrowed by U.S. Banks Before Fed Credit Squeeze, Wall St. J., Oct. 19, 1979, at 33, col. 1.

For a suggestion by the Cliairman of Citibank, Walter Wriston, that United States banks may use the Eurodollar market in a similar nuanner in the future, see Controlling the Markets, Euromoney, June 1979, at 7. Cf. Close Encounters: Was Law Firm's Study of Citibank's Dealings 
Given the economic and pohtical instability that often arises in these countries, a Euro-bank's loan portfoho centered on these investments carries a high risk of incurring the consequences of the borrower's failure and default. In addition, when the troubled debtor is a sovereign government, the pohitical problems associated with resolving loan probleins are numerous and complex. ${ }^{44}$

\section{Extended Loan Maturities}

In the Eurodollar market, banks have been inaking loans for progressively longer terms. ${ }^{45}$ Euro-banks commonly have extended term loans of five to seven years, ${ }^{46}$ and even ten to fifteen years. ${ }^{47}$ This is required by the long term capital intensive projects for which the funds are being secured. ${ }^{48}$ Longer inaturities tend to increase risks, since uncertainties about the ability of the borrower to repay a loan increase with time. ${ }^{49}$ The inost stalwart borrower's circuinstances inay change drastically because of political, economic, or technological events beyond its control..$^{50}$

Longer terms also expose a Euro-bank to financial losses if the interest rates it pays on deposits and for funds in general rises above that rate at which funds were lent. ${ }^{51}$ To protect themselves froin this situation, Eurodollar loan agreements typically reserve for the lender the option of adjusting the interest rates every three or six inonths. ${ }^{52}$

Abroad a Whitewash?, Wall St. J., Sept. 14, 1982, at 1, col. 6 (Securities and Exchange Commission alleged that Citibank 'parked' money in various currencies in its overseas branches in order to avoid restrictions on foreign exchange transactions.); Gerth, Records Show Citicorp Acted To Skirt Foreign Bank Rules, N.Y. Times, Sept. 13, 1982, at A1, col. 1.

44. See, e.g., Farnsworth, I.M.F. Role In Poland Talks Set, N.Y. Times, Aug. 19, 1981, at D1, col. 3. See also Brazil Debates Renegotiating Its Huge Debt, Wall St. J., Aug. 25, 1982, at 24, col. 3 ("After Mexico, Brazil has the second highest foreign debt in the Third World."); In the Shadow of the Dollar: Bridging Gaps in Mexico, N.Y. Times, Aug. 25, 1982, at A22, col. 1 ("Mexico's financial crisis . . . has global dimensions."); Riding, The Crisis in Mexico, N.Y. Times, Aug. 23, 1982, at A1, col. 3; Western Banks' Talks With Poles Hits Some Snags, Wall St. J., Aug. 13, 1982, at 21, col. 1; Reformed Debtor? How Romanians Fell into Economic Hole, Rebuffing Creditors, Wall St. J., July 28, 1982, at 1, col. 6.

45. See, e.g., S. Robinson, supra note 2, at 253. Cf. L. Goodman, Eurodollars AND the U.S. Money Supply 9-10 (Fed. Reserve Bank N.Y., Resenrch Paper No. 8001 Jan. 1980) (on file with the California Law Review).

46. See, e.g., J. LiTTLE, supra note 4, at 89; F. Klopstock, supra note 5, at 2.

47. Weinert, supra note 25 , at 36 .

48. Bell, supra note 5 , at 17.

49. F. Klopstock, supra note 5 , at 5.

50. Id.

51. G. BeLL, supra note 2, at 34 .

52. Gaines, Manufacturers Hanover Trnst Economic Report: The Eurocurrency Market 1 (Sept. 1972) (on file with the California Law Review). This revolving credit technique allows banks to match the maturities of their Eurodollar assets and liabilities. G. BELL, supra note 2, at 34; Bell, supra note 5, at 17. 
The interest risk is thus passed on to the borrower. ${ }^{53}$ Yet the risk that the borrower will default remains, and in fact increases, if interest rates are very high. ${ }^{54}$

\section{Instability of Eurodollar Deposits}

Euro-bank lending based on time deposits of Eurodollars may involve more risk than normal commercial bank lending based on demand deposits, other things being equal, since demand deposits are considered to be somewhat more stable than time deposits. Demand deposits are generally used to settle basic and recurring transactions and thus must be kept at fairly constant levels. Conversely, time deposits are subject to disintermediation-the transfer of time deposit funds to the bond market or other financial vehicles. ${ }^{55}$ Particularly vulnerable are Euro-banks that borrow short (e.g., by accepting three-month time deposits) ${ }^{56}$ and lend long (e.g., by lending for five to seven years) ${ }^{57}$ In the event of large unexpected withdrawals of deposits, the imbalance between the inaturities of the bank's dollar assets (the inflow of funds as interest and principal to the bank) and its dollar liabilities (the outflow of funds on deposit at the bank) would result in severe liquidity problems. ${ }^{58}$

This possibility of large witlidrawals is not entirely theoretical. Substantial funds, which have been placed in the Eurodollar market witl very short term maturities, ${ }^{59}$ could be switched from Eurodollars into solne other investment medium. Such a change would wreak havoc with Euro-banks' liquidity management, ${ }^{60}$ particularly since many Eurodollar loans are channeled into long term projects, such as oil refineries, alumimuin smelters, and other capital intensive projects. ${ }^{61}$

\section{The Pyramiding Risk}

The greatest potential weakness in Eurodollar banking stems from

53. F. Klopstock, supra note 5 , at 3.

54. If Eurodollar lenders were suddenly to become more conservative in their loans, borrowers would have more difficulty renewing their obligations at maturity. McRae, The Market in 1971-Weathering the Currency Turmoil, EuROMONEY, July 1972, at 6, 7.

55. C. Campbell \& R. Campbell, An Introduction to Money and Banking 202-03, 275 (2d ed. 1975). See generally Bankers Are Fretting as Their Customers Flock to Teller Windows to Close Out Time Deposits, Wall St. J., Mar. 31, 1980, at 32, col. 1.

56. J. LrTTLE, supra note 4, at 23.

57. See Morgan Guaranty Trust Co., supra note 35, at 8; E. Clendenning, supra note 5, at 163; S. RoBINSON, supra note 2, at 25.

58. BANK FOR INT'L SETTLEMENTS, ForTY-FifTH ANNUAL REPORT 33, 133 (1975); Morgan Guaranty Trust Co., supra note 35, at 8.

59. Morgan Guaranty Trust Co., supra note 35 , at 8.

60. Id. See also The Euro-Dollar Market, supra note 25, at 28.

61. Bell, supra note 5, at 17. 
the common practice of Euro-banks to lend and relend among themselves at small profit margms. This process continues as long as the banks are willing to relend to each other, ${ }^{62}$ or until a Euro-bank lends to a nonbank borrower. ${ }^{63}$

Since the liquidity of eacl participant or link in the chain depends on the financial strength of the ultimate borrower, ${ }^{64}$ if one large borrower in the system, either a bank or other person, defaults, ${ }^{65}$ the remaining banks participating in the chain may be unable to stem the collapse of the network. A Euro-bank's ratio of cash on hand to Eurodollar loans is typically sinall, and because the banks normally have no reserve for bad debts, a loan default would effectively elininate a large part of their capital base. ${ }^{66}$ In the absence of government intervention, bank failures would inevitably result. ${ }^{67}$ Given the small profit margms (approximately $0.5 \%$ to $0.625 \%$ net armually) associated with pyramiding loans, ${ }^{68}$ one would expect few banks to be willing to undertake such enormous financial risks. That pyramiding continues to exist to the extent that it does in Eurodollar inarkets suggests the absence of prudent and conservative banking practice.

\section{B. The Benefits}

There are benefits as well as risks in the Eurodollar market. One significant benefit of the market has been the increase in competition among European banks. ${ }^{69}$ This coinpetition has aided the development of the European capital markets, thereby causing more efficient mobilization of investment funds. ${ }^{70}$

Another beneficial byproduct of the Eurodollar network is the increased closeness of the various financial markets around the world. ${ }^{71}$ Even without the Eurodollar inarket, soine increased freedom in the movement of funds would have resulted from the Treaty of Roine and

62. Normally, subsequent borrowers must pay successively higher rates of interest. The Euro-dollar Market, supra note 25, at 16.

63. The Euro-dollar Market, supra note 25, at 15; Gerth, supra note 32.

64. See Holmes \& Klopstock, supra note 1, at 202.

65. Gaines, supra note 52, at 2.

66. Weinert, supra note 25 , at 38 .

67. Whether the banks should be assisted has been the subject of some debate. See Bennett, Moral Issue in Congress: Punish the Big Banks?, N.Y. Times, July 26, 1983, at D3, col. 1.

68. Id. See also F. Klopstock, supra note 5, at 7. See generally Lending at Less Than Prime Rates Produces a PR Problem for Banks, Wall St. J., Feb. 27, 1981, \& 2, at 21, col. 3; Crittenden, Euroloan Markets Feel Profit Squeeze, N.Y. Times, Dec. 3, 1978, $\$ 3$ (Business and Finance), at 3, col. 4. In the case of a loan syndication, the managing bank also earns a fee for its services.

69. Holmes \& Klopstock, supra note 1 , at 8.

70. See Gaines, supra note 52, at 1 . The results have probably been higher interest rates earned by depositors and lower interest rates paid by borrowers.

71. The Euro-dollar Market, supra note 25, at 29, 37. 
the new cooperative attitudes that accompanied it. ${ }^{72}$ Nonetheless, the ability of banks to enter an established market for dollar deposits and swap those dollars for other currencies lias been conducive to the formation of an even more closely integrated banking system. ${ }^{73}$

In weighing the costs and benefits of the Eurodollar market, one authority concludes:

In spite of all [its] dangerous possibilities, the conclusion that seems to emerge . . . is that, pending the acquisition of further experience, the advantages [of the Eurodollar market] appear to outweigh the disadvantages by a fair margin . . . . It would be a sad day for mankind if it were ever to decide to renounce progress for the sake of avoidimg the risk attached to it.

So far we are only familiar with the operation of the system in fair weather. Even so, the results which have already been achieved are substantial and their extent justifies the taking of further risk-within reason.

A limitation of the degree of risk has been achieved by spreading the risk among a large number of banks participating in syndicates for roll-over credits in which form Euro-dollars are re-lent, also by the more active interest taken by the monetary authorities in the operation of the system. There is, however, scope for further improvement. ${ }^{74}$

The caveat, another authority concludes, is that, "[D]espite the great opportunities whicl the Eurodollar inarket undoubtedly offers . . . it is well to bear in mind [that] 'tlis market is not for the unsophisticated." "75

III

REgULATION

\section{A. The Desirability of Regulation}

As described in Part II, the structural weaknesses of the Eurodollar market present a strong argument for some kind of regulation. ${ }^{76}$

72. See E. Clendenning, supra note 5, at 172-74; Norton \& Hansen, Reflections Upon Economic and Monetary Union in the European Community, 11 TEX. INT'L L.J. 251, 256 (1976).

73. United States banks have used the Eurodollar nuarket extensively to borrow dollars from their European branches. See J. LitTLE, supra note 4, at 112-13.

74. P. Einzig, The Euro-Dollar System: Practice and Theory of International INTEREST RATES 151 (5th ed. 1973).

75. Effros, supra note 16 , at 644 .

76. This need for regulation of the Eurodollar narket has not gone unrecognized. See, e.g., E. ClendenNing, supra note 5, at 168; Gaines, supra note 52, at 4; F. Klopstock, supra note 5, at 8-9. But see, e.g., Weinert, supra note 25 , at 37.

As financiers and businessnien have increasingly perceived the dangers of default and inflation, discussion of international monetary reform has becone lively. See, e.g., STAFF of JoINT Economic Comm., 95Th Cong., 1st Sess., Some Questions ANd Brief ANSwers About THE Eurodollar Market (Comm. Print 1977); Bank For INTERNational SETrlements 45TH ANNUAL REPORT 133-34 (1975); Hutton, The Regulation of Foreign Banks-A European Viewpoint, 10 
Even though the Eurodollar market has survived and grown for over two decades, there remains a serious risk of a substantial economic upheaval if the market were to undergo severe strams. Such an upheaval would have widespread effects on the world economy. ${ }^{77}$ It is ironic that doinestic banking, with the same or perhaps lower risks, is normally subject to government regulation, while Eurodollar banking, with its potential for disruptimg international financial networks, is not. ${ }^{78}$

The inere presence of risk, however, does not require a full-fledged regulatory response. The difficulties that attend any regulation are not trifling. Regulation, however rudimentary and narrow in scope, is a restriction on freedoin and coinpetition. Even if minimized, the consequences of this restriction still present substantial problems, coinplications, and costs. ${ }^{79}$ These burdens nay be worth incurring, but for any regulation to be politically feasible it inust pass a balancing test whereby the costs of the negative aspects of the regulation are perceived to be outweighed by the resultant benefits of greater security for the international financial community, ${ }^{80}$ and for the public interest generally. ${ }^{81}$ In economic terms, this cost-benefit equation can be stated as whether the marginal cost of regulation is equal to or less than the narginal benefits in the forin of reduced risks resulting from the regulation.

COLUM. J. WORLD BUS., Winter 1975, at 109, 109-10; Regulation of Multinational Banking Institutions, 3 J. Comp. CORP. L. \& SEC. REG. 49 (1981). See also supra note 36 and accoinpanying text.

77. See, e.g., P. EINZIG \& B. QuinN, supra note 2, at 116-17.

78. But the Eurodollar market is not entirely free of regulation. See supra note 24 and accompanying text.

79. See, e.g., Kristol, The Hidden Costs of Regulation, Wall St. J., Jan. 12, 1977, at 14, col. 4; Kohlmeier, There's Data, Dala Everywhere. . . And a Lot of It's Useless According to Businessmen, N.Y. Times, Jan. 9, 1977, $\S 3$ (Business and Finance), at 15, col. 1. But even self-regulation can be bureaucratically burdensome. See, e.g., J. LITTLE, supra note 4, at 92-93 (concerning dealers who formed the International $C D$ Credit Market Association to standardize market operations).

80. See Debs, Petro-Dollars, LDC's and International Banks, 58 FED. RESERve BANK N.Y. Monthly Rev. 17 (1976); see also Gerth, Budget Office Against New Rules Requiring Bank Disclosure, N.Y. Times, Aug. 31, 1982, at A1, col. 5.

81. See, e.g., F. Beutel, Bank Officer's Handbook of Commercial Bankino law 5 (4th ed. 1974). New York's policy is stated clearly:

It is hereby declared to be the policy of the state of New York that the busmess of all banking organizations shall be supervised and regulated through the banking departinent in such manner as to insure the safe and sound conduct of such business, to conserve their assets, to prevent hoarding of money, to eliminate unsound and destructive coinpetition among such banking organizations and thus to maintain public confidence in such business and protect the public interest and the imterests of depositors, creditors, shareholders and stockholders.

N.Y. BANKING LaW $\S 10$ (McKinney 1971). See also, e.g., Regulation K, 12 C.F.R. $\$ 211$ (1983) (regarding supervision of foreign operations of inember banks of the Federal Reserve System). Cf. Greenberg, Accounting and the Law, im HaNDBook of Accounting AND Auditing 45-12 to 45-13 (J. Burton, R. Palmer \& R. Kay eds. 1981). 


\section{B. Categories of Regulation}

Banking regulation in general falls into two nonexclusive categories-inacroeconomic and microeconomic. These categories correspond to the types of risks they are designed to control. Macroeconomic regulations control unonetary aggregates and, therefore, affect prices and interest rates. Microeconomic regulation is designed to control the risk to which banks are subjected, that is, the risks of default and bank insolvency. Those regulations that include both microeconomic and inacroeconomic eleinents directly affect the inflation risk as well as the default risk.

\section{Macroeconomic Regulation}

The traditional macroeconomic regulatory tool is the reserve requirement. This control works by limiting the extent to which financial imstitutions can relend their deposits. Generally administered by a central monetary authority, these regulations control the liquidity in the economy.

An alternative inechanisin that a government may use to effect macroeconomic control of monetary aggregates is through its participation in capital markets. By entering the capital markets and either buying or selling currency or Treasury bills, a nation's nonetary authority can increase or decrease the liquidity in the econoiny. This change in an econouny's liquidity in turn affects foreign nations because of the high degree of integration of world capital markets.

\section{Microeconomic Regulation}

Whereas macroeconomic regulation strives to influence factors that affect the entire econoiny, microeconomic controls are designed to insure individual bank solvency and to limit the default risk. Soine examples of microeconomic control in the United States include: entry restrictions facing new banks, restrictions on lending, restrictions on investment activity, and requireinents for banks to offer insurance for depositors against loss because of insolvency. Reserve requireinents nnay even be considered an indirect microeconomic control, since they promote solvency by preventing illiquidity of the bank's investinent portfolio.

Microeconomic regulations that might be considered in the Eurodollar market include: limits on pyramiding, qualification requirements on loans to lesser developed countries, and limits on the maturity structure of Eurodollar portfolios. Additionally, it has been suggested that international organizations, such as either the International Monetary Fund or the Bank for International Settleinents, scru- 
tinize loans to lesser developed countries to ensure the enforceability and prudence of such investments. ${ }^{82}$

Although an understanding of the two regulatory categories is useful in considering what solutions are available to the problems inherent in the Eurodollar market, simply proposing traditional currency control methods is not enough. A more fundamental question that first must be answered is whether any traditional regulatory model can provide a feasible response to Euro-banking's problems. ${ }^{83}$

\section{The Feasibility of Regulation}

The first requirement for any Eurodollar regulatory scheme is uniformity. Participants in the Eurodollar market can be expected to seek out the least regulated sectors-a phenomenon perhaps best described as a regulatory shopping effect. To be effective, therefore, Eurodollar regulation must be uniforn across the participating countries. There are two approaches to obtaining this transnational uniformity of Eurodollar regulations - either multinational agreement or unilateral action.

\section{Unilateral Action}

The United States is in a unique position, as the generator of dollar currency, to achieve some measure of Eurodollar regulation through unilateral action. Such single nation action might take two shapes: Eurodollar market elimination or forced inultinational regulation.

Market elimination would prohibit the export of American currency. By refusing to allow the dounestic currency to leave the country, the Umited States could unilaterally "control" the Eurodollar inarket. Eliminating foreign ownership of dollars, however, is impracticable. First, regulations that would work by stopping the flow of capital out of the country would be isolationist and counterproductive. The United States has an enorinous number of international economic links, with transactions occurring constantly. Second, the admimistrative mechamisms required to monitor all avenues of currency flows do not pres-

82. See, e.g., Janssen, IMF Subjected to Increasing Pressure to Widen Its Role in World Economics, Wall St. J., Oct. 14, 1980, at 36, col. 1; Janssen, IMF Insuranee of Loans to Poor Nations Is Urged by Bank of America's Clausen, Wall St. J., June 4, 1980, at 6, col. 2; IMF Should Beconie World Central Bank, Its Chief Says, Offering 'Workable' Plan, Wall St. J., Oct. 29, 1975, at 21, col. 2. The IMF has been hesitant to assume such a rolc, however. See generally Clark, International Monetary System Flourishes, Wall St. J., Sept. 7, 1982, at 27, col. 4. For a discussion of the Bank for International Settlements' possible role, see Lee, supra note 5, at 67-68.

83. See, e.g., Sweeney \& Willett, Eurocurrency Markets Not Source of Infation; Regulation Unnecessary, Money Manager, Dec. 15, 1975, at 7, col. 1 (emphasizing the difficulty of achieving international agreement to impose an effective reserve requirement on Eurocurrency banks). 
ently exist. That such a regulatory structure could be created is uncertain, given the reahties of current patterns of international finance. The United States dollar is widely held throughout the world and contimues to be a leading means of international payment. Finally, the costs attendant to any unilateral attempt by the United States to eliminate the Eurodollar inarket would be very large.

A second regulatory strategy would be for the United States to control unilaterally the flow of Eurodollars, short of prohibition. Either the Federal Reserve Board or the Comptroller of the Currency ${ }^{84}$ could, for example, pressure the home offices of American banks with branches abroad. ${ }^{85}$ The weakness of this strategy, however, is that American banks do not control the dollar funds held by foreign banks. Simce a significant amount of all Eurodollars is held by foreign banks and sovereign nations, any American program to control overseas trade in dollar currency would be of limited efficacy.

As outlined, therefore, unilateral regulation fails even the most cursory cost-benefit analysis. The benefits of a nuore stable Eurodollar market do not outweigh the potential disruptiveness of American regulation of international money markets, particularly simce most Eurodollar transactions will take place in countries beyond the regulatory grasp of the United States.

\section{Multinational Agreements}

Simce no international body exists with the authority to require Eurodollar regulation within countries, unanimous agreement among the nations mvolved is a prerequisite for multinational regulation. The difficulty of forming and maintaining such a cartel of nations acts as an enormous barrier to effective transnational regulation. Two inodels for securing multimational agreeinent can be postulated. The first model is forced multimational regulation. This method consists of a foreign country exerting its imfluence and power over international commerce to compel other countries to act in concert. This strategy is virtually identical to unilateral action described above but seeks as its object agreement among countries.

One mechanism to exert this degree of coercion would be for the controlling nation to suspend trade or most-favored-nation status with any country that failed to agree to a multmational systein of Eurodollar regulation. Althougln this tactic is sometimes used by nations for polit-

84. See Edwards, Extraterritorial Application of the U.S. Iranian Assets Control Regulations, 75 AM. J. INT'L L. 870 (1981); F. Klopstock, supra note 5, at 9-10; Fed Moves to Bring Foreign Banks in U.S Under Rules Governing Domestic Firms, Wall St. J., Nov. 13, 1980, at 6, col. 1.

85. See F. Klopstock, supra note 5, at 9; Miller, Limits Formally Proposed on Bank Lending Overseas, N.Y. Times, Jan. 9, 1978, at D1, col. 2. 
ical reasons, its use to regulate the Eurodollar market is not particularly attractive. Its coercive foundation breeds hostility and destroys the cooperative spirit essential to any long-term multimational agreement. Beyond pragmatic considerations, such coerced agreements violate a sovereign nation's right to control its own transnational transactions. The control of one nation's internal pohies by another strips the weaker country of its basic independence. The pohtical volatility of forced inultinational action combimed with the limited gains involved in Eurodollar regulation when compared with the pain of such regulation makes this option neither desirable nor feasible.

A second regulatory alternative would be for the Euro-bank participants to pursue some form of self-regulation. This strategy has three flaws. First, Euro-banks do not beheve that the current situation in the Eurodollar market is a cause for alarm. ${ }^{86}$ Second, even if a group of banks adopted a voluntary program of regulation, the action's effectiveness would be quite limited unless competitors followed suit. It is possible that other banks would spontaneously follow such a lead, but the extent of cooperation would necessarily depend on the acceptability of the controls initiated by the first bank. Third, any system of voluntary regulation iniposed solely among Euro-banks would be inherently unstable, because its members would often have conflicting interests. Banks located in countries with relatively hight regulation profit handsomely from their positions as intermediaries; such banks would chafe under industry regulation. These Euro-banks have significant volume and profits, which in turn benefit the country in which they are located through greater econounic activity and the intangible gains of prestige. For exainple, London's role as a financial center is a major support to Britain's economy. As a result, these Euro-banks would have strong nationalistic incentives to break from the cartel to attract deposits and to make loans. ${ }^{87}$ Although transnational self-regulation by Euro-banks would certainly be a desirable first step, given the present highly competitive climate of international banking, it does not appear feasible.

As outlined above, the mechanics of multinational Eurodollar regulation could take many forms-the only essential requirement being

86. See, e.g., Controlling the Markets, supra note 43, at 7 (comments of Walter Wriston, chairman of Citibank). For a survey concerning the imposition of reserve requirements on Eurodollar deposits, sec 'The Banker' Opinion Survey, BANKER, Mar. 1978, at 24 (76\% of bankers surveyed were opposed).

87. As an example of the ability of econoumic incentives to overcome governinent regulation, recently New York created a special tax zone to place local banks on the same footing as those elsewhere in the world. See, e.g., America's Debut in Offshore Banking, N.Y. Times, Nov. 22, 1981, § 3 (Business), at 1, col. 3; New York's New Financial Markets, N.Y. Times, Nov. 16, 1980, $\S 3$ (Business), at 1 , col. 2 . 
the creation of a consensus. Such a consensus poses the most significant obstacle to any multinational regulation, the European Monetary Systein notwithstanding. ${ }^{88}$

International political agreements are exceptional occurrences, especially when inore than two nations are imvolved. Negotiations are usually burdened by past political feuds between nations and great logistical difficulties. Internal political obstacles also exist. Because of their importance, enforceable agreements are often subject to special ratification procedures. In the United States, for example, nnajor international agreements are negotiatied by the Executive but must be ratified by two-thirds of the Senate. ${ }^{89}$ Thus procedural, political, and practical problems incident to any international agreement make such an agreement very difficult to organize and to bring to fruition.

Even if an agreement could be reached, its long-terin viability im the face of stresses arising from the integration of the world's capital markets and the rapid flow of inoney across national borders is questionable. As transportation and commurncations between nations have become faster and easier, the world's capital inarkets have become highly integrated. Capital can be moved very easily. Any international banking agreement designed to control short-tern capital markets would have to be flexible enough to meet the demands of this extremely fluid market. In particular, any regulatory regime would have to be designed to forestall the capital drain that would surely result from the flow of funds froin newly regulated Euro-banks to noncontrolled financial institutions, or sovereign havens, such as the Cayman Islands or Switzerland. ${ }^{90}$

Any regulatory system sufficiently flexible to meet tlie Eurodollar market's demands, however, would be politically difficult to sustain. A Eurodollar agreement and attendant regulatory system would be subject to both the internal political pressures of each participant country and to international politics generally. Given the fragility of any transnational accord, it would be very difficult to impose sanctions on countries that failed to abide by its ternns. (1981).

88. See, e.g., Gamble, The Treaty/Custom Dichotomy: An Overview, 16 TEx. INT'L L.J. 305

89. U.S. CoNST. art. II, \& 2, cl. 2.

90. See, e.g., Coudert, The Regulation of Foreign Banking in Japan, Singapore, and Hong Kong, 91 BANkING L.J. 822 (1974); Note, Foreign Bank Secrecy and the Evasion of United States Securities Laws, 9 N.Y.U. J. INT'L L. \& POL. 417 (1977). On Luxembourg as a haven, see Lewis, Foreign Banking Rush to Luxembourg Wanes, N.Y. Times, Dec. 8, 1980, at DI, col. 3. Euro-banks can now transfer funds electronically with great speed, which may make evasion and sudden large shifts easier. See, e.g., Risk Allocation in International Interbank Electronic Fund Transfers: CHIPS and SWIFT, 22 HARv. INT'L L.J. 621 (1981); Janssen, Fed's Task May Be Tougher After Oct. I, As Banks Quicken International Clearing, Wall St. J., Apr. 20, 1981, at 2, col. 3; Multinationals Worry As Countries Regulate Data Crossing Borders, Wall St. J., Aug. 26, 1981, at 1, col. 6. 
Given all these obstacles, it is extremely unlikely that an international agreement is a feasible solution to the regulatory dilemma created by Eurodollars. No inatter how desirable a inultinational accord might be in theory, it is a remote solution in practice.91

\section{IV \\ DisClosure}

As shown in the prior discussion, the Eurodollar market presents a quandary. Many authorities beheve that Euro-banks do not practice prudent banking and that these banks are dangerously overextended. ${ }^{92}$ The absence of reserve requirements and the difficulty of securing repayment from imternational borrowers make Eurodollar loans more risky than domestic transactions. Additionally, the inarket probably exerts inflationary pressures on the economy.

At the same time, the imternational character of the market precludes simple remedies. The difficulty of securing agreement and enforcing the controls, while mamtaining the flexibility required by Eurobanking, renders traditional regulatory solutions meffective. The administrative overhead of traditional regulation is formidable and such regulations are not enforceable. Sophisticated Eurodollar financiers, knowledgeable of the relative risks and returns of various money markets, and the degree of regulation in the different banking systems of the world, would outmaneuver any fixed regulatory system. ${ }^{93}$ It is necessary, therefore, to formulate alternative strategies that allow a proper balance between freedom of action im the market and greater security.

One such solution might be to require Euro-banks to disclose the nature and character of Eurodollar loan recipients. ${ }^{94}$ Subject to the

91. There exists an informal committee known as the "Group of Ten," made up of members of central banks whose countries are involved in the Eurodollar market. Its success, however, has been limited. See, e.g., Central Banker's Euromart Fears Ease and Korean Lenders Get Brief Vaca. tion, Wall St. J., June 23, 1980, at 26, col. 1; Group of Ten Bankers Set Up Unit to Watch International Dealings, Wall St. J., Apr. 16, 1980, at 4, col. 4.

92. See supra note 25.

93. See supra note 90 .

94. Under any system of disclosure, ample protections of confidentiality and privacy would be required. Such safeguards should limit the garnering of infornation based on its relevance for legitimate purposes. See, e.g., 5 U.S.C. \& 555(c)-(d) (1976). Questions of confidentiality and privilege unight be resolved in a fashion similar to the rules regardmg personal information in the Federal Reserve record system, implementing the Privacy Act of 1974, 5 U.S.C. § 552(a) (1976); see 12 C.F.R. \& 261 a.1 (1983). See generally Alexander \& Spurgeon, Privacy, Banking Records and the Supreme Court: A Before and After Look at Miller, 10 Sw. U.L. REv. 13 (1978); Smith, The Public's Need for Disclosure v. the Individual's Right to Financial Privacy: An Introduction to the Financial Right to Privacy Act of 1978, 32 AD. L. REv. 511 (1980); Westim, Privacy in the Banking Relationship: The Federal Government as a Source of Primary Problems and a Possible Part of the Solution, 34 Bus. Law. 1129 (1979); Note, Is There a Right of Privacy in Bank Records? Different Answers to the Same Questions: California vs. Federal Law, 10 LoY. L.A.L. REv. 378 (1977); Note, 
scrutiny of a supranational agency, these disclosure requirements would enable Euro-banks to aggregate data in order to assess more accurately the risks of each Eurodollar loan they made. The extent of the information required by disclosure would be determined in light of the combimed experience of the Euro-banks and monetary authorities in the countries in which Euro-banks operate. ${ }^{95}$

Disclosure does not directly limit market participants' actions. Rather, it is an indirect regulatory approach. Disclosure enables regulatory authorities to evaluate present conditions which may, in turn, facihtate an investigation of the advisability of more direct regulation.

Like traditional regulatory models, however, disclosure must also pass a cost-benefit analysis. The costs of disclosure depend directly on the extent and precision required. Effective disclosure can be obtained at low cost where the information is normally collected for internal use. For example, smce all Euro-banks presumably keep internal records on the characteristics of their loan portfolios to determine the risk and profitabihity of mdividual investments, disclosure of this data would impose few additional costs on the banks. The benefits to both banks and society, such as avoiding insolvency, far outweigh the small additional expense of accumulating and collating the information for disclosure.

Costs of disclosure regulations, however, mcrease when reporting regulations require information not normally prepared by the Eurobanks themselves. Requirimg banks to accumulate and to aggregate loan information not currently prepared internally would result in additional expenses-both in formulating data retrieval systems and im developing processing methods to handle this information once retrieved. The question of what mformation will be subject to disclosure, therefore, controls the cost-benefit acceptability of any disclosure proposal.

To help discern what degree of disclosure might be required under a Eurodollar monitoring system, a brief survey of bank disclosure regulations $\mathrm{m}$ force in the United States is instructive. ${ }^{96}$ Although these

No Expectation of Privacy in Bank Records-United States v. Miller, 26 DE PaUl L. REv. 146 (1976).

95. Bettner, Your Money Matters: Do You Know Who is Borrowing Money? Penn Square Bank Failure Raises the Question, Wall St. J., Aug. 9, 1982, at 34, col. 1 (The "question of how much disclosure [to depositors and to shareholders] is adequate is becoming an increasingly complicated one." But "an official of a New York banking trade group who did not want to be identified [said] 'What right do depositors have to second guess management? That's the regulators' role.'").

96. The following discussion does not purport to be an exhaustive compilation of the various kinds of information that could be disclosed under particular guidelines or regulations. Any admimistrative processes, however incomplete they may be at imcipiency, should be fiexible enough to create whatever rules are appropriate (or to abrogate, if necessary, any mappropriate rules) for 
requirements do not exhaust the range of possibilities, they are a useful and fairly extensive source of ideas. Also, to the extent that these regulations rely on internally generated information, the cost to banks of imposing disclosure requirements is small.

The Federal Reserve System has two disclosure requirements that provide useful models for any proposed Eurodollar disclosure system. Regulation $\mathrm{F}$ requires banks to submit analyses of loans made. ${ }^{97} \mathrm{Al}-$ though based primarily on internal operations data, these reports provide for the presentation of information on the bank's balance sheet of loans extended and on provisions inade for loan losses.

Another Federal Reserve Board disclosure requirement is Regulation $\mathrm{K},{ }^{98}$ which pertains to foreign activities of national banks. This regulation requires banks to disclose information on risks, hquidity management, internal bank controls, the conformance of bank activities to manageinent policies, and the results of internal and external audits of their foreign branches. ${ }^{99}$ Reports must be detailed enough to permit the Federal Reserve to appraise the credit quality of the foreign branch's borrowers and to assess exposure to risk.

The Securities and Exchange Commission bank disclosure requirement provides an alternative approach. Its Statistical Disclosure Guides ${ }^{100}$ are designed to elicit information regarding banks' loan portfolios in order to gauge their exposure to risk. ${ }^{101}$ At the end of each reporting period, the Guides require the banks to provide separate information on: (1) commercial, financial, and agricultural loans; (2) real estate construction loans; (3) real estate inortgage loans; (4) installment loans; and (5) foreign loans. ${ }^{102}$ Information on the risk aspects of a bank's loans are requested, although such information is difficult to quantify. ${ }^{103}$ The bank has to disclose which loans involve a reasonable

the disclosure of material information. Nevertheless, the potential scope of any particular serics of guidelines or any particular series of regulations can be outlincd as a starting point. By no ineans all of the examples suggested here would have to be promulgated to have a workable systcm. Banks would appear to have the capacity to compile various data. Fed Amends Its Rules 10 Allow Bank Firms to Offer Data Services, Wall St. J., Aug. 24, 1982, at 41, col. 1.

97. 12 C.F.R. $\S 206$ (1982). See also Securities Exchange Act of 1934 Disclosure Rules Form F-4, 12 C.F.R. \& 206.44 (1982) (quarterly report form). These regulations parallel those of the Comptroller of the Currency, 12 C.F.R. $\$ 11.44$ (1982).

98. 12 C.F.R. $\$ 211$ (1982).

99. 12 C.F.R. $\$ 211.7(a)(1)-(2)(1982)$.

100. 15 U.S.C. \& 77(a) (1976 \& Supp. V 1981); see also 1982 SEC Integrated Disclosure Adop. tions, FED. SEC. L. REP. (CCH) No. 956 (1982).

101. See Statistical Disclosure by Bank Holding Companies, Securities Act of 1933 Guide 3 item III.B, 1 FED. SEC. L. REP. (CCH) I 3827, at 3327 (Mar. 7, 1983) (former Guide 61/Guide 3 by 1 redesignated FED. SEC. L. ReP. (CCH) I 3760 (Mar. 3, 1982)).

102. See id. item III.A, 1 FED. SEC. L. REP. (CCH) ๆ 3827, at 3326.

103. See id. item III.C, 1 FED. SEC. L. REP. (CCH) \ 3827, at 3327. 
risk of default on either principal or interest, in whole or in part. ${ }^{104} \mathrm{~A}$ summary of loan loss experience is included, ${ }^{105}$ and the bank has to state the dates of maturities for time deposits of $\$ 100,000$ or more. ${ }^{106}$ The bank also has to state what the gross amount of interest income would be if all loans were current. ${ }^{107}$

Another model for banking disclosure is that required by the semiaumual Country Exposure Lending Survey of the Federal Reserve, the Federal Deposit Insurance Corporation, and the Comptroller of the Treasury. ${ }^{108}$ The survey is an aggregation of data prepared by banks on their overseas loans, including loans between foreign branches of American banks and residents in another country and loans denouninated in a currency other than the home currencies of the borrower. The survey requires the following information: the types of loans made; the types of borrowers; the loan inaturities; and information on loan guarantees and other commitments to provide funds.

The disclosure possibilities suggested by these different regulations could be extended inuch further. There is a wealth of possibilities, and care should be taken that too many requirements are not imposed in regulating Eurodollars. ${ }^{109}$ Soine disclosure inechanism, however, should be feasible to implement, and might even be welcomed by the banks involved. ${ }^{110}$

\section{V \\ CONCLUSION}

This Article has only touched on some of the potential weaknesses inherent in the current Eurodollar market. The loan practices followed by many Euro-banks expose the systein to financial imstabihity. Overextended, pyraumided portfohios containing long-term obligations, which rely heavily on unstable lesser developed countries for repayment, plague many Eurodollar lenders. Additionally, deposit expansion of Eurodollar assets is considered a fundainental source of world inflation.

104. See id.

105. See id. item IV, I FED. SEC. L. REP. (CCH) \ 3827, at 3327-30.

106. See id. item V, 1 FED. SEC. L. REP. (CCH) I 3827, at 3329.

107. See id. See also id. item IV, 1 FED. SEC. L. REP. (CCH) I 3827, at 3327-30.

108. See A New Supervisory Approach to Foreign Lending, 3 FEd. REserve Bank N.Y. Q. ReP., Spring 1978, at 1; Uniform Examination Procedure, 64 FED. Reserve BuLL. 920 (1978). The survey covers American banks and their branches abroad.

109. See, e.g., S. Ross, Disclosure Regulation in Fimancial Markets: Implications of Modern Fimance Theory and Signaling Theory (Mar. 1977) (unpublished manuscript on file with the California Law Review). See also Kristol, supra note 79, at 14, col. 4.

110. That bankers might welcome some means to regularize Eurodollar market activities is evidenced by their imdependent, voluntary efforts, albeit limited, at self-regulation. See supra notes $6 \& 91$. 
One source of the weakness in the Eurodollar market that can be eliminated without undue pohitical or economic costs or barriers is the lack of information about borrowers. The diversification of most Eurodollar portfohios and the common practice of nondisclosed relending makes it very difficult for Euro-banks to track the ultimate recipients of Eurodollar loans.

The problem of lack of information about Eurodollar transactions can be resolved through the regulatory alternative of disclosure. Such a quasi-regulatory system could have more lasting, long-term influence on the world Eurodollar market than a harsh, unenforceable system of Eurodollar control. The ability of Eurodollar participants to shop for the least restrictive jurisdiction is an incentive for countries to seek the unost efficient possible regulatory stance. It has been concluded that the end result of regulation is "usually that the economy incurs the cost of enforcement and suffers the loss of efficiency caused by the controls ... yet the desired effect remains elusive because funds flow through alternative channels." 111

The formulation of administrative standards for disclosure of Eurodollar transactions will require a gradual process of trial and error. To the extent that the information involved is already generated internally by Euro-banks for risk evaluation, the cost of requirmg that internal data be disclosed and of aggregating it would be low. The banks involved would have to aid in formulatimg the guidelines, since they best understand the demands of confidentiality. Whether the guidelines should coine from the banks entirely, or from the monetary authorities of the countries involved, remains to be seen. If the banks can work together and fashion a plan themselves, no government action will probably be needed. But if they continue without a system of disclosure, then national regulators will be forced to enter the vacuum to establish guidelines.

Disclosure of loan portfolio information among Eurodollar market participants could take many shapes. This Article has focused briefiy on some American models as a starting point. These disclosure regulations can provide information upon which Eurodollar requirements could be formulated. Keeping in mind the constant deunands for flexibility, confidentiality, and unformity, Eurodollar participants should be able to fashion a preliminary data-gathering network.

Although the Eurodollar system has, thus far, provided an enorinous source of investment capital and opportunity for world financial markets, the possibility of a potential economic disaster should be enough to inotivate further efforts to regularize Euro-bank lending

111. See Dufey \& Giddy, supra note 28 , at $60-61$. 
practices. It is to be hoped that studies and articles such as this will help to focus concern about the future of Eurodollar banking and to suggest some tentative solutions and reasonable compromises. 